\title{
Palaeoproterozoic to Eoarchaean crustal growth in southern Siberia: a Nd-isotope synthesis
}

Dmitry P. Gladkochub ${ }^{1}$, Tatiana V. Donskaya ${ }^{1}$, Steven M. Reddy ${ }^{2}$, Ulrike Poller ${ }^{3}$, Tamara B. Bayanova ${ }^{4}$, Anatoliy M. Mazukabzov ${ }^{1}$, Sergei Dril ${ }^{5}$, Wolfgang Todt $^{3} \&$ Sergei A. Pisarevsky ${ }^{6}$

${ }^{1}$ Institute of the Earth's crust, Siberian Branch of the Russian Academy of Sciences, 128 Lermontov St., 664033 Irkutsk, Russia (e-mail: dima@crust.irk.ru)

${ }^{2}$ The Institute for Geoscience Research, Dept. of Applied Geology, Curtin University of Technology GPO Box U1987Perth, WA 6845, Australia

${ }^{3}$ Max-Plank Institute für Chemie, Postfach 3060, 55020 Mainz, Germany

${ }^{4}$ Geological Institute of Kola Scientific Centre of the Russian Academy of Sciences, 14 Fersmana, 184209, Apatity, Russia

${ }^{5}$ Institute of Geochemistry, Siberian Branch of the Russian Academy of Sciences, 1 Favorsky St., 664033 Irkutsk, Russia

${ }^{6}$ School of GeoScience, University of Edinburgh, King's Buildings, West Mains Rd, Edinburgh EH9 3JW, UK

corresponding author:

Dr. Dmitry Gladkochub

Number of words of text $\mathbf{-} 8405$

Number of references -59

Number of tables -1

Number of figures -3

Abbreviated title: Crustal growth in southern Siberia 


\begin{abstract}
$\mathrm{Nd}$-isotope analyses from 114 rock samples are reported from the southern part of the Siberian craton to establish a first-order crustal formation scheme for the region. The $\mathrm{Nd}$ isotope data show considerable variability within and among different cratonic units. In many cases this variability reflects differing degrees of mixing between juvenile and older (up to Eoarchaean) crustal components. The fragments of Palaeoproterozoic juvenile crust within the studied segment of the Siberian craton margin have Nd model ages of $\sim 2.0-2.3$ $\mathrm{Ga}$. Voluminous Palaeoproterozoic granites $(\sim 1.85 \mathrm{Ga})$ were intruded into cratonic fragments and suture zones. These granites mark the stabilization of the southern Siberian craton. The complexity in the Nd data indicate a long history of crustal development, extending from the Eoarchaean to the Palaeoproterozoic eon, which is interpreted to reflect the amalgamation of distinct Archaean crustal fragments, with differing histories, during Palaeoproterozoic accretion at $1.9-2.0 \mathrm{Ga}$ and subsequent cratonic stabilisation at $1.85 \mathrm{Ga}$. Such a model temporally coincides with important orogenic events on nearly every continent and suggests that the Siberian craton participated in the formation of a Palaeoproterozoic supercontinent at around 1.9 Ga.
\end{abstract}

Keywords: Siberian craton, Precambrian, Nd-isotope system, isotope provinces, terrane, Palaeoproterozoic supercontinent 
The Siberian craton is one of the largest Early Precambrian lithospheric units of Northern Eurasia, extending for a distance over $2500 \mathrm{~km}$ from the Arctic Ocean in the north to Lake Baikal in the south. The craton comprises five major provinces (superterranes) (Aldan, Anabar, Olenek, Stanovoy, Tungus) and two large-scale orogenic belts (Angara and Akitkan) (Fig. 1a) that are defined on lithological, structural and geophysical (gravity and magnetic anomaly) data (Rosen et al., 1994; 2005). The amalgamation of these blocks to form the Siberian craton was initially assumed to have taken place from $\sim 1.9-2.1 \mathrm{Ga}$ (Condie and Rosen 1994). This has recently been confirmed by radiometric dating of granulite-facies metamorphic rocks and collision-related granites located at the margins of the different blocks (Nutman et al., 1992; Donskaya et al., 2002; Turkina et al., 2003, 2006; Poller et al., 2004, 2005; Rosen et al., 2005; Gladkochub et al., 2006a; Larin et al., 2006; Sal'nikova et al., 2007 etc.).

Recently, northern and eastern parts of the Siberian craton have been extensively studied to investigate the crustal-formation ages of terranes that make up these areas of the craton (Parfenov et al., 2001 and references therein). Geochronological data from igneous rocks and metamorphic complexes of southern Siberia (Fig. 1a) indicate tectonic activity in spanning 3.39 - 1.85 Ga (Bibikova et al., 2006; Neymark et al., 1998; Poller et al., 2005; Turkina et al., 2005; Sal'nikova et al., 2007). Magmatic zircons as old as 3.39 Ga (Bibikova et al, 2004) and 3.39 Ga inherited zircon cores from Palaeoproterozoic granulites (Poller et al., 2005) indicate the likely presence of Early Archaean crust in the southern part of the Siberian craton. However, the interior structure and the variation in crustal-formation age in the different crustal blocks that form the southern part of the craton are currently poorly known. In this paper, a synthesis of published geochronological data is combined with 109 new Sm-Nd analyses from the southern Siberian craton. These new data record the variation in $\mathrm{Nd}$ isotopic compositions within the main crustal blocks, establish variations in crustalformation age and assess whether the different crustal components were derived from isotopically juvenile material or older continental crustal components. This is the most comprehensive synthesis of crustal age distribution in southern Siberia so far, and provides an assessment of the continental growth record of the region during the Archaean and Palaeoproterozoic.

\section{Geological setting and main unit descriptions}

The two largest cratonic blocks of the Siberian craton (Anabar and Tungus) and the Angara and Akitkan orogenic belts are all found within the southern Siberian craton in the proximity of Irkutsk (Fig. 1a). However, the majority of the Siberian craton is overlain by Mesoproterozoic - Neoproterozoic and Phanerozoic sediments such that only a few small areas of basement crop out. These areas are principally the Birusa, Sharizhalgai, Goloustnaya, Baikal terranes and the Urik-Iya terrane (Fig. 1b). According to recent studies, 
the Birusa terrane is considered as the southern termination of the Angara orogenic belt; the Sharizhalgai terrane represents the southern part of Tungus block; and the Goloustnaya and Baikal terranes are the southern building blocks of the Akitkan orogenic belt (Fig. 1a) (Rosen et al.; 2005; Gladkochub et al., 2006a). The Urik-Iya terrane is thought to represent a graben comprising Palaeoproterozoic sediments that now separates the Birusa and Sharizhalgai terranes (Gladkochub et al., 2002).

The Birusa terrane comprises amphibolite facies gneisses, migmatites, schists and rare amphibolites. Within the metamorphic complex are numerous thick layers of quartzites, marbles and high-Al gneisses. Although the dominant metamorphic grade in the Birusa terrane is amphibolite facies, relicts of retrograde granulites are locally preserved and indicate a complex metamorphic history in the terrane basement (Turkina et al., 2003). ${ }^{207} \mathrm{~Pb} /{ }^{206} \mathrm{~Pb}$ zircon ages of $\sim 1.90 \mathrm{Ga}$ from biotite gneiss are interpreted as the age of the amphibolite facies metamorphic event (Turkina et al., 2006). The ages of post-tectonic tonalites, granites and diorites record a restricted age range to $1.86-1.87 \mathrm{Ga}$ (Turkina et al., 2006). The youngest anorogenic granite intrusions within the Birusa terrane yield a zircon crystallisation age of $1.75 \mathrm{Ga}$ (Turkina et al., 2003). The Early Precambrian basement of the Birusa terrane is also intruded by Neoproterozoic (741 Ma) mafic dykes and sills thought to have formed during the breakup of Rodinia (Gladkochub et al., 2006b). Early Palaeozoic (500 Ma) mafic dykes and sills are related to accretion, and subsequent extension, of several microcontinents during the earliest stages of Palaeoasian ocean closure within the Central Asian orogenic belt to the south (Donskaya et al., 2000; Gladkochub et al., 2008).

The Sharizhalgai terrane is located to the south-west of the Birusa terrane (Fig. 1b) and is well exposed for up to $400 \mathrm{~km}$ from the Urik River to the southern part of Lake Baikal. The Sharizhalgai terrane consists of two major tectonic units, the Onot-Erma domain and Irkut-Kitoy domain. Both of these domains comprise orthogneisses and migmatites of felsic and mafic composition interlayered with and sillimanite-bearing paragneiss, marbles and schists. These rocks record amphibolite and granulite facies metamorphic conditions.

At the western margin of the Sharizhalgai terrane, the Onot-Erma domain (Fig. 1b) comprises a lower metamorphic sequence composed of TTG-orthogneisses, relicts of amphibolites, orthogneiss (metadacite), marbles and quartzites. The U-Pb zircon age of TTG-orthogneisses of the Onot-Erma basement yields one of the oldest ages reported for the Siberian craton at $3.39 \mathrm{Ga}$ (Bibikova et al., 2006). This is similar to U-Pb age of inherited zircon cores determined from granulites exposed in the Irkut-Kitoy domain (Poller et al., 2005). On the basis of U-Pb zircon data, both domains comprise two main periods of metamorphism at $\sim 2.6 \mathrm{Ga}$ and $\sim 1.9 \mathrm{Ga}$ (Aftalion et al., 1991; Poller et al., 2005; Sal'nikova et al., 2007).

The metamorphic rocks of the Sharizhalgai terrane are intruded by the Neoarchaean (2.53 Ga) Kitoy granites (Gladkochub et al., 2005), Palaeoproterozoic (1.85 - 1.86 Ga) 
Sayan and Shumikha granites (Donskaya et al., 2002; Levitskii et al., 2002) and Neoproterozoic (0.74 - 0.76 Ma) mafic dykes (Sklyarov et al., 2003; Gladkochub et al., 2006b).

The Birusa and Sharizhalgai terranes are separated by the amphibolite facies volcanic-sedimentary rocks of the Palaeoproterozoic Urik-Iya terrane (Fig. 1b). The western contact of the Urik-Iya terrane with the Birusa terrane is marked by $1.86 \mathrm{Ga}$ post-collisional granites (Levitskii et al., 2002) that intrude the Urik-Iya volcano-sedimentary sequence. To the east, the contact with the Sharizhalgai terrane unit is marked by Palaeoproterozoic fault. This eastern part of the Urik-Iya terrane contains relicts of eclogite facies mafic-ultramafic rocks and associated metavolcanics and metasediments (pelites, quartzites and marbles). Based on field and geochemical characteristics, this association of rocks has been interpreted as a dismembered and metamorphosed ophiolite sequence of Palaeoproterozoic $(\sim 1.9 \mathrm{Ga})$ age that separated the Birusa and Sharizhalgai domains (Gladkochub et al., 2001a). Recently, numerous strongly tectonised fragments of this potential ophiolite have been found in the marginal part of the Sharizhalgai terrane (Gladkochub et al., 2001a).

In the central (axial) zone of the Urik-Iya terrane a younger sequence of unmetamorphosed coarse-grained terrigenous rocks (sandstones and conglomerates) are intruded by dykes of anorogenic porphyritic granite. This age of this granite has been constrained by ${ }^{40} \mathrm{Ar} /{ }^{39} \mathrm{Ar}$ biotite dating and yields an age of $1.53 \mathrm{Ga}$ (Gladkochub et al., 2002). This date provides a minimum age for sedimentation related to intracratonic extension within the Urik-Iya unit.

To the north-east of the Sharizalgai terrane lie the Goloustnaya and Baikal terranes. According to the modern tectonic interpretation of the Siberian craton (Rosen et al., 2005; Gladkochub et al., 2006a) both of these terranes belong to the Akitkan orogenic belt (Fig. 1a). The Goloustnaya terrane is well exposed on the western shore of Lake Baikal (Fig. 1b). This terrane comprises gneisses, foliated granites and amphibolites. The age of foliated granites have been determined by SHRIMP and TIMS U-Pb zircon methods which yield ages of $2.02 \mathrm{Ga}$ and $2.04 \mathrm{Ga}$ respectively (Poller et al., 2005). The basement complex of the Goloustnaya terrane is intruded by $1.86 \mathrm{Ga}$ post-collisional granite of the Primorsk complex (Donskaya et al., 2003). The Baikal terrane (Fig. 1b) is exposed along the Lake Baikal shore and comprises Neoarchaean (2.88 Ga) (Donskaya et al., 2005a) and Palaeoproterozoic (1.91 - $2.02 \mathrm{Ga}$ ) (Bibikova et al., 1987; Neymark et al., 1998; Larin et al., 2006) foliated granites and Palaeoproterozoic volcanic-sedimentary sequences (Sarma and Chuya Groups). The Sarma Group rocks are interpreted to be fragments of a dismembered back-arc basin, while the Chuya Group represents arc material (Neymark et al., 1998). Consequently, the Sarma and Chuya Groups are considered have formed at the Palaeoproterozoic active-margin of the Siberian craton.

The basement complex rocks of the Baikal terrane record a wide range of metamorphic pressure - temperature (PT) conditions from predominantly lower greenschist 
facies to locally preserved granulite facies mineral assemblages. Granulite facies metamorphism has been dated by U-Pb dating of zircon at $1.88 \mathrm{Ga}$ (Poller et al., 2005) and has been interpreted to reflect a collisional event along this segment of the craton's southern margin (Gladkochub et al., 2006a).

The basement rocks of the Baikal terrane are unconformably overlain by a younger, unmetamorphosed Palaeoproterozoic volcanic-sedimentary sequence (Akitkan Formation). The lower part of this formation contains mafic volcanic rocks while its upper parts are more felsic. The sedimentary rocks in this formation are sandstones and siltstones. U-Pb zircon dating of felsic volcanic rocks of the Akitkan Formation, sampled at different parts of the Baikal terrane, is reported at 1.85 - 1.87 Ga (Larin et al., 2003; Donskaya et al., 2007).

Within the Baikal terrane there are numerous massifs of undeformed and unmetamorphosed post-collisional 1.85 - 1.87 Ga granitoids (Neymark et al., 1991; Poller et al., 2005; Larin et al., 2006). Some of these Palaeoproterozoic granitoids (e.g. the Irel Complex) are considered to be co-magmatic intrusions associated with the felsic volcanics of the Akitkan Formation (Neymark et al., 1991). According to recent constraints on the tectonic evolution of southern Siberian craton, the Akitkan volcanic-sedimentary sequence, as well as granites mentioned above, are considered to have formed during post-collision extension immediately after the main collision event reported for the area at $\sim 1.9 \mathrm{Ga}$ (Larin et al., 2003; Donskaya et al., 2005b; Poller et al., 2005; Gladkochub et 1., 2006b). In contrast to $\sim 1.85-1.87 \mathrm{Ga}$ post-collisional complexes, the Chuya granite complex intruding the metamorphosed volcanic-sedimentary sequence of the Chuya Group (eastern flank of the Baikal terrane, see Fig. 1b) records a slightly older age $(2.02 \mathrm{Ga})$ and geochemical affinities typical for island-arc granitoids (Neymark et al., 1998; Larin et al., 2006).

Three intracratonic mafic dyke complexes have a local distribution within the Baikal terrane. The age of the oldest mafic dykes is reportedly similar to the mafic volcanics of the Akitkan Formation (Gladkochub et al unpublished U-Pb zircon SHRIMP data). Younger dykes yield a Sm-Nd mineral-whole rock isochron age 1.67 Ga (Gladkochub et al, 2007). The youngest dike intruded into the Archaean and Palaeoproterozoic complexes of the Baikal terrane have Neoproterozoic ages $(\sim 0.79 \mathrm{Ga})$ and are associated with rifting related to the Rodinia breakup (Gladkochub et al., 2007).

\section{Analytical Approach and Methodology}

$\mathrm{Sm}-\mathrm{Nd}$ isotope data are commonly used to determine the timing of continental crust formation, and identify possible rock sources (DePaolo and Wasserburg, 1976). The $\mathrm{Nd}$ model age calculation for igneous rocks produced by partial melting of mantle source is based on the assumption that the major chemical fractionation of Sm and $\mathrm{Nd}$ took place when the source material was derived from depleted mantle (DM), i.e. prior to its incorporation into the crust (e.g. McCullogh, 1987; Jahn and Condie, 1995). This requires 
that intra-crustal processes, such as crystal fractionation, do not affect the initial $\mathrm{Sm} / \mathrm{Nd}$ ratios (Taylor and McLennan, 1985). There is empirical support for this assumption since Sm-Nd systems appear to remain undisturbed during multiple deformation events (Barovich and Patchett, 1992) and even granulite-facies metamorphism (Whitehouse, 1988). Consequently, a "single-stage" evolution model produced by a single (uniform) magma source yields positive values of $\varepsilon \mathrm{Nd}(\mathrm{T})$ that indicate short-lived juvenile sources whereas negative values of $\varepsilon \mathrm{Nd}(\mathrm{T})$ are typical for rocks produced by reworking of longlived crustal materials.

It should be noted that caution is warranted where multiple sources and magmas mixing may be present. In the cases where mixed sources are likely, for example some igneous felsic rocks close in chemical composition to I- and A-type granites (hereafter granite abbreviations are given according to Chappell and White, 1974; Whalen et al., 1987; Liew et al., 1989), Nd model ages do not reflect the correct age of crust-forming events and demonstrate $\mathrm{Nd}$ model ages older than the true age of melting (Arndt and Goldstein, 1987). However these data provide indirect evidence for the existence of older crustal components within the source region and are therefore useful for tectonic interpretations.

Sedimentary rocks composed mainly of material derived from a single source (uniform type of sediments, according to Dickin, 2005) may yield useful constraints on the model age of the source. However, Nd model ages of sedimentary rocks produced by several sources (mixed sediments) only yield the minimum $\mathrm{Nd}$ model age of their crustal provenances (Dickin, 2005). Consequently, better interpretation of $\mathrm{Nd}$ data from sediments requires isotopic analysis to be coupled with petrological analysis that allow potential source components to be identified. However in both cases Sm-Nd characteristics of sedimentary rocks may provide useful provenance information (Dickin, 2005).

The Nd isotope system of meta-sedimentary rocks may be disturbed during diagenesis and metamorphic processes (Stille and Clauer, 1986; Bros et al., 1992; Bock et al., 1994 and Cullers et al.,1997). However, for such kind of samples it is possible to use a "two-stage" model age calculation (Keto and Jacobsen, 1987).

In this study, the Sm-Nd systematics of numerous mafic intrusions (dykes/sills), widespread within the studied area, have been investigated. All of these are strongly contaminated by crustal components (Gladkochub et al., 2001a; 2006b). Consequently, the $\mathrm{Nd}$ isotope characteristics can only be used to provide constraints on the $\mathrm{Nd}$ model age of the crustal components.

For this study, unweathered geochemical samples were collected from sample locations given in Table 1 . The samples were crushed, averaged, and approximately $300 \mathrm{~g}$ of the resulting material was pulverised using an agate mill. For mineral separation, the crushed material was ground using a rotary mill to a grain size $<500 \mu \mathrm{m}$. For Sm-Nd, 
XRF and ICP-MS analyses, the fine grained $(<50 \mu \mathrm{m})$ powder from the agate mill was used.

Isotopic measurements presented in the paper were carried out at the Max-PlanckInstitut (MPI) für Chemie in Mainz, Germany, the Geological Institute of the Kola Science Centre RAS (GI KSC RAS), Apatity, Russia, the Institute of Precambrian Geology and Geochronology of the RAS (IPGG RAS), St Petersburg, Russia, the Institute of Geochemistry of the Siberian Branch of the Russian Academy of Sciences (IGC SB RAS), Irkutsk, Russia and at Hokkaido University (HUni), Sapporo, Japan. In MPI, IPGG RAS and HUni the measurements were carried out using Finnigan MAT 261 mass spectrometers. In the case of GI KSC RAS and IGC SB RAS Finnigan MAT 262 mass spectrometers were used. All systems employ multiple collectors operating in static mode. The analytical $\mathrm{Sm} / \mathrm{Nd}$ procedures are described in detail by Poller et al. (2001) for MPI, White and Patchett (1984) for HUni, Neymark et al. (1993) for IPGG RAS and IGC SB RAS and in Bayanova (2004) for GI KSC RAS.

The total laboratory blanks were: $0.06 \mathrm{ng}$ for Sm and $0.3 \mathrm{ng}$ for Nd in GI KSC RAS, IGS SB RAS and Hokkaido Uni, $<100 \mathrm{pg}$ for Nd and Sm in MPI, $0.03 \mathrm{ng}$ for Sm and 0.1 0.5 for Nd in IPGG RAS. All ${ }^{147} \mathrm{Sm} /{ }^{144} \mathrm{Nd}$ and ${ }^{143} \mathrm{Nd} /{ }^{144} \mathrm{Nd}$ ratios were normalized to ${ }^{146} \mathrm{Nd} /{ }^{144} \mathrm{Nd}$ values of 0.7219 and ${ }^{143} \mathrm{Nd} /{ }^{144} \mathrm{Nd}$ values of 0.511860 or 0.512100 reported for the La Jolla and JNdi-1 Nd standard respectively. The weighted mean ${ }^{143} \mathrm{Nd} /{ }^{144} \mathrm{Nd}$ values for the La Jolla Nd standard during the period of measurements were $0.511839 \pm 7(n=13)$ in IPGG RAS, $0.511833 \pm 6(\mathrm{n}=11)$ in GI KSC RAS, $0.511835 \pm 9(\mathrm{n}=20)$ in MPI, and $0.511831 \pm 7(\mathrm{n}=12)$ in Hokkaido Uni; values for the JNdi-1 Nd standard were 0.512092 ( $\mathrm{n}$ $=10)$ in IGC SB RAS. The $\varepsilon_{\mathrm{Nd}}(\mathrm{T})$ values and model ages $\mathrm{T}_{\mathrm{DM}}$ were calculated using the currently accepted parameters of CHUR $\left({ }^{143} \mathrm{Nd} /{ }^{144} \mathrm{Nd}=0.512638\right.$ and $\left.{ }^{147} \mathrm{Sm} /{ }^{144} \mathrm{Nd}=0.1967\right)$ (Jacobsen and Wasserburg, 1984) and depleted mantle $\left({ }^{143} \mathrm{Nd} /{ }^{144} \mathrm{Nd}=0.513151\right.$ and $\left.{ }^{147} \mathrm{Sm} /{ }^{144} \mathrm{Nd}=0.2136\right)$ (Goldstein and Jacobsen, 1988). Errors on isotopic ratios are quoted at the $2 \sigma$ level.

\section{Nd isotope data for the southern Siberian craton}

\section{Birusa terrane}

The studied gneisses of the Birusa terrane basement show a narrow range of Sm and $\mathrm{Nd}$ concentrations (5.44 - 6.47 ppm and 30.13 - 32.68 ppm respectively) (Table 1). ${ }^{147} \mathrm{Sm} /{ }^{144} \mathrm{Nd}$ ratios display typical crustal values $(0.1052-0.1091)$ indicating that wholerock $\mathrm{Sm} / \mathrm{Nd}$ system remained undisturbed during metamorphism. As U-Pb zircon age of the gneisses is unknown, initial $\varepsilon \mathrm{Nd}$ values were calculated for $\mathrm{t}=1900 \mathrm{Ma}$ which is considered to be a minimum for main metamorphic event in the region (Turkina et al, 2006). The 
analysed gneisses are characterized by $\varepsilon \mathrm{Nd}(\mathrm{T})$ values between -3.6 and -6.5 (Fig. 2) and have corresponding $\mathrm{Nd}$ model ages ranging between $2.57-2.81 \mathrm{Ga}$ (Table 1, Fig. 3).

The Nd isotope characteristics of seven granites (S, I and A-types) of the Birusa terrane have been investigated. Among these rocks, S-type granites (based on mineral composition and chemical affinities, see Donskaya et al., 2005c) display mostly negative $\varepsilon \mathrm{Nd}(\mathrm{T})=$ up to -6.3 and maximum $\mathrm{Nd}$ model age of $2.74 \mathrm{Ga}$. Both of these values are similar to $\varepsilon \mathrm{Nd}(\mathrm{T})$ and $\mathrm{Nd}$ model age of the Birusa terrane gneiss (sample 33-81, Table 1).

Palaeoproterozoic I- and A-type granites demonstrate variable values of $\varepsilon \mathrm{Nd}(\mathrm{T})$ (from -1.6 to -5.3) and $\mathrm{Nd}$ model ages range from 2.39 - $2.61 \mathrm{Ga}$ (Table 1, Figs. 2, 3). These variations in $\mathrm{Nd}$ model age reflect the variable mixing proportion of the Palaeoproterozoic mantle-derived material and Archaean crustal source represented by the nearby Birusa greisses (Fig. 2). The mantle-derived material input into the Podporog A-type granite source $(\varepsilon \mathrm{Nd}(\mathrm{T})=-4.8$ to -5.3$)$ is estimated at about $35 \%$, while for the Uda granite $(\varepsilon \mathrm{Nd}(\mathrm{T})=-1.6$ to -2.4$)$ it is estimated at around $40-50 \%$ (Turkina et al., 2006).

Two main groups of dolerite intrusions are widespread in the Biryusa terrane. The first group is represented by Neoproterozoic dolerite sills (741 Ma) that are found in the passive margin volcanic-sedimentary sequence (Gladkochub et al., 2006b). Younger mafic dolerite dykes $(511 \mathrm{Ma})$ intrude basement rock and the Neoproterozoic sediments (Gladkochub et al., 2006b). Both groups of dolerite have enriched LREE profiles with ${ }^{147} \mathrm{Sm} /{ }^{144} \mathrm{Nd}=0.1274-0.1310$, very low $\varepsilon \mathrm{Nd}(\mathrm{T})$ values $(-12.1$ up to -12.6$)$ and $\mathrm{Nd}$ model ages of $2.40-2.71 \mathrm{Ga}$ (Table 1, Fig. 3). The $\varepsilon \mathrm{Nd}(\mathrm{T})$ values of dolerites extended to very negative values and $\mathrm{Nd}$ model age variations are consistent with varied degrees of the original melts being contaminated by much older (at least NeoArchaean) continental crust (Fig. 2). Other geochemical characteristics, reported by Gladkochub et al (2006b), support the inference that the dolerites were sourced from mantle-derived melts contaminated by crustal components.

\section{Sharizhalgai Terrane}

\section{Onot-Erma Domain}

Onot-Erma TTG-orthogneisses of the Onot-Erma basement yield a narrow range of $\mathrm{Nd}$ model ages, with a mean $\mathrm{T}_{\mathrm{DM}}$ age of $3.55 \mathrm{Ga}$. This model age is $160 \mathrm{Ma}$ older than the 3.39 Ga U-Pb zircon age of Onot-Erma TTG-orthogneiss (Bibikova et al., 2006). The Nd isotope data of Onot-Erma TTG-orthogneisses $(\varepsilon \mathrm{Nd}(\mathrm{T})$ range from +1.7 to -0.6$)$ suggest an older evolved crustal component in this region (Turkina, 2004, Turkina et al., 2007) (Fig. 2, Table 1).

The youngest $\mathrm{Nd}$ model age of orthogneisses (metadacite) of the Onot-Erma unit is 3.28 Ga (Fig. 3) while the Nd model age (3.49 Ga) of amphibolite relicts among TTG- 
orthogneisses of the Onot-Erma basement is similar to the TTG-orthogneisses model age. Positive value of $\varepsilon \mathrm{Nd}(\mathrm{T})=2.2$ estimated for the amphibolite corresponds to a $\mathrm{DM}$ value at 3.57 Ga (Fig. 2). Thus, Nd isotope composition of this amphibolite indicate a signature of juvenile Palaeoachaean crust in the Onot-Erma unit (Turkina, 2004).

Four samples of unmetamorphosed post-collisional A-type granitoids of Palaeoproterozoic age (1.86 Ga) (Donskaya et al., 2002; Turkina et al., 2006) from the Onot-Erma unit show a narrow range in ${ }^{147} \mathrm{Sm} /{ }^{144} \mathrm{Nd}(0.1013-0.1119)$ (Table 1). Their $\varepsilon \mathrm{Nd}(\mathrm{T})$ (at $\mathrm{T}=1861 \mathrm{Ma}$ ) values are remarkably similar ranging from -7.4 to -8.3 . Because of the insignificant variation in ${ }^{147} \mathrm{Sm} /{ }^{144} \mathrm{Nd}$, the depleted-mantle model ages from these granitoids show minimal variation $(2.78-2.93 \mathrm{Ga}$; Table 1$)$, suggesting a relatively homogenous source.

The difference between the $\mathrm{Nd}$ model age $(2.78-2.93 \mathrm{Ga})$ and $\mathrm{U}-\mathrm{Pb}$ zircon age $(1.86 \mathrm{Ga})$ of A-type granitoids exposed in the Onot-Erma unit indicate that the granitoids were derived from sources with long-crustal residence time. The $\mathrm{Nd}$ model ages of A-type granitoids are distinctly younger than the model age of their possible crustal source (Palaeoarchaean TTG-orthogneisses with Nd model age 3.55 Ga) (Fig. 3) and indicate mixture of Palaeoproteorozoic juvenile mantle-derived material with an older crustal source (Fig. 2) (Donskaya et al., 2005b; Turkina et al., 2006).

\section{Irkut-Kitoy Domain}

Metamorphic rocks of the Irkut-Kitoy Domain attained peak high-grade conditions around 2.6 Ga (Poller et al., 2005) and comprise the following: mafic rocks with chondritic REE profiles, ${ }^{147} \mathrm{Sm} /{ }^{144} \mathrm{Nd}=0.2014$, and $\varepsilon \mathrm{Nd}(\mathrm{T})$ of +1.7 (at $\mathrm{T}=2.62 \mathrm{Ga}$ ); mafic and intermediate rocks with LREE enrichment, ${ }^{147} \mathrm{Sm} /{ }^{144} \mathrm{Nd}=0.1421-0.1121$, and $\varepsilon \mathrm{Nd}(\mathrm{T})$ of 4.2 to -13.2 ; and metasediments, some with significant LREE enrichment, ${ }^{147} \mathrm{Sm} /{ }^{144} \mathrm{Nd}$ up to 0.0833 , and $\varepsilon \mathrm{Nd}(\mathrm{T}$ ) of -0.2 to -9.7 (at $2.62 \mathrm{Ga}$ ). The $\varepsilon \mathrm{Nd}$ depleted mantle value of +1.7 in the Irkut-Kitoy mafic granulite (sample 0329) indicates a juvenile depleted-mantle Palaeoarchaean source. The rest of the metamorphic rocks of the Irkut-Kitoy domain can be considered as reworked Neoarchaean ( 2.6 Ga, after Poller et al., 2004; 2005) relicts of older Archaean lower (granulites after mafic and intermediate rocks) and upper (granulite after sediments) crust. Mean Nd model age of lower crust relicts vary from 3.34 - 3.94 Ga (Figs. 2, 3), and fit to the range $2.94-3.79 \mathrm{Ga}$ for upper crust relicts.

Three analysed granites $(81605,02161$ and 0354$)$, which are typically transitional I$\mathrm{S}$ type according to their chemical composition, have been derived through melting of mainly volcanic-sedimentary sources (Gladkochub et al., 2005). Nd model ages of these rocks $(2.73-3.17 \mathrm{Ga})$ are fairly consistent in $\mathrm{Nd}$ model age of upper crustal gneisses of the Sharizhalgai terrane (Table 1, Fig. 2).

Palaeoproterozoic I-type granites (Table 1) formed through melting of an igneous or intracrustal source yield lower $\varepsilon \mathrm{Nd}$ values, reflecting possible the mixing of the 
Palaeoproterozoic mantle-derived material and Archaean crustal source. Neodymium isotope studies provide support that the change in Palaeoproterozoic granite geochemistry from I-S-type $(\varepsilon \mathrm{Nd}(\mathrm{T})=-10.7)$ to I-type (minimum $\varepsilon \mathrm{Nd}(\mathrm{T})=-6.9)$ reflecting an addition of mantle-derived magmatic source material (Fig. 2).

The Sm-Nd whole rock isotope systematics from five Neoproterozoic mafic dykes intruding the basement of the Sharizhalgai terrane has been investigated. All analysed samples are calc-alkaline in composition and have geochemical characteristics indicating they were sourced from mantle-derived melts contaminated by crustal components (Gladkochub et al., 2007). These dykes are slightly LREE-enriched $\left({ }^{147} \mathrm{Sm} /{ }^{144} \mathrm{Nd}=0.1710-\right.$ 0.1500 ) and have intrusion ages of $0.76 \mathrm{Ga}$ (Sklyarov et al., 2003).

The initial $\varepsilon_{\mathrm{Nd}}$ values, calculated for the intrusion age of the dykes, range from -7.8 to -18.2 and yield linear correlations with estimated $\mathrm{Nd}$ model ages (from $2.75 \mathrm{Ga}$ at $\varepsilon \mathrm{Nd}(\mathrm{T})$ $=-7.8$ to $3.97 \mathrm{Ga}$ at $\varepsilon \mathrm{Nd}(\mathrm{T})=-18.2)$ (Table 1$)$. These correlations can be explained as reflecting different degrees of contamination of mantle derived magma by early Precambrian crustal components of the Sharizhalgai terrane. In general the lowest $\varepsilon N d$ value (dolerite sample 8330) may indicate more crustal involvement in its genesis. Nevertheless, as indicated by the $\mathrm{Nd}$ model ages, the crustal component required for mixing must at least be of Archaean age.

\section{Urik-Iya terrane}

Metamorphosed under eclogite facies (Sklyarov et al., 1998) mafic rocks within the Urik-Iya terrane (7008g in Table 1) yield close to chondritic REE ratios, ${ }^{147} \mathrm{Sm} /{ }^{144} \mathrm{Nd}=$ 0.1944 and $\varepsilon \mathrm{Nd}$ value -0.2 at $1.88 \mathrm{Ga}$ (Table 1), a reasonable minimum age of eclogite metamorphism in the area (Gladkochub et al., 2001a). This $\varepsilon N d$ value is interpreted to represent mixing of juvenile and older crustal components both of Palaeoproterozoic age.

To the north-west, across away from the suture zone, mature sandstone of the UrikIya terrane (sample $1517 \mathrm{~b}$, in Table 1 ) is slightly enriched in LREE $\left({ }^{147} \mathrm{Sm} /{ }^{144} \mathrm{Nd}=0.1350\right.$ ) and has an initial $\varepsilon \mathrm{Nd}(\mathrm{T})$ value of 2.7 at $1.86 \mathrm{Ga}$. We used this age value as time of possible disturbance of Sm-Nd system in rock studied, related to voluminous post-collisional granite intrusions in the area (Levitskii et al., 2002; Donskaya et al., 2002). A two step Nd model age of the mature sediment of $2.13 \mathrm{Ga}$ indicates Palaeoproterozoic crust as possible source for this sandstone.

Mesoproterozoic (1.53 Ga) anorogenic I-type granite (Gladkochub et al., 2002) intrudes basement and sedimentary sequence of the Urik-Iya terrane and records LREE enrichment $\left({ }^{147} \mathrm{Sm} /{ }^{144} \mathrm{Nd}=0.0912\right)$ and initial $\varepsilon N d$ value -5.9 . The $\mathrm{Nd}$ model age of the granite is $2.33 \mathrm{Ga}$ (Table 1). The geochemical affinities of the granites indicate their generation by melting of tonalitic crustal basement of the Urik-Iya terrane (Gladkochub et al., 2002). 


\section{Goloustnaya terrane}

The basement of the Goloustnaya terrane comprises gneisses which are LREE enriched $\left({ }^{147} \mathrm{Sm} /{ }^{144} \mathrm{Nd}=0.1072\right)$ and record initial $\varepsilon \mathrm{Nd}(\mathrm{T})$ value -4.6 for $1.86 \mathrm{Ga}$; the time of possible Sm-Nd system disturbance by large-scale granite intrusions (Donskaya et al., 2003). The $\mathrm{Nd}$ model age of the Goloustnaya terrane gneisses is $2.62 \mathrm{Ga}$ and is younger than the Nd model age of the nearby basement rocks of the Sharizhalgai terrane (Table 1). As we used the only Nd data for the Goloustnaya basement complex we did not show it on Fig. 2.

Two I-type granitoids demonstrate a narrow range in ${ }^{147} \mathrm{Sm} /{ }^{144} \mathrm{Nd}(0.0931-0.0936)$. Their $\varepsilon N d$ values are similar and range from -0.9 to -1.8 (at $2.0 \mathrm{Ga}$, the time of their intrusion, see Poller et al., 2005) with depleted-mantle model ages showing little variation 2.44 - $2.50 \mathrm{Ga}$ (Table 1). In contrast to the I-type granites, A-type granite (Primorsk complex) intruding the Goloustnaya gneiss basement displays more "crustal" values of $\varepsilon N d(T)(-6.1)$ and an older Nd model age (2.7 Ga). The data for A- and I-granites indicate a more significant crustal contribution of a Neoarchaean crustal source in A-type granites than in the I-type granitoids of the Goloustnaya terrane.

\section{Baikal terrane}

The lower crustal metamorphic rocks of the Baikal terrane are not exposed, so only the Mesoarchaean foliated TTG-type granitoids of the Baikal terrane are available for $\mathrm{Nd}$ isotopic study (Donskaya et al., 2005a). These rocks record typical crustal values for ${ }^{147} \mathrm{Sm} /{ }^{144} \mathrm{Nd}(0.0717-0.0967)$ and display no major $\mathrm{Sm} / \mathrm{Nd}$ fractionation during Palaeoproterozoic metamorphic event reported in the region (Poller et al., 2005; Gladkochub et al., 2006a). TTG-type granitoids show $\varepsilon N d(T)$ values estimated for time of their emplacement (2.88 Ga, Donskaya et al., 2005a) between +0.8 and -1.6. The Nd model ages of the granitoids range between $3.07-3.23 \mathrm{Ga}$ which are below the depleted mantle line (Table 1, Figs. 2, 3)..

The Sm-Nd isotopic systematics of seven whole rock from the Palaeoproterozoic metamorphosed sedimentary of the Sarma Group have been investigated (Table 1). For all of these samples, the $\varepsilon \mathrm{Nd}(\mathrm{T})$ and two-stage $\mathrm{Nd}$ model ages were calculated for $\mathrm{T}=1.88 \mathrm{Ga}$, which is considered to be a minimal age of the main metamorphic event capable to affect on Sm-Nd system of the samples. The metamorphosed mature sandstones display a narrow range in ${ }^{147} \mathrm{Sm} /{ }^{144} \mathrm{Nd}(0.0953-0.1206)$, negative value of $\varepsilon \mathrm{Nd}(\mathrm{T})$ (from -2.1 to -8.8) and maximum two-stage $\mathrm{T}_{\mathrm{DM}}$ values of $3.08 \mathrm{Ga}$. Such values of $\mathrm{Nd}$ model age are similar to the $\mathrm{Nd}$ model age of the TTG-type granitoids, indicating the possibility that these may be the 
major source for Sarma Group sandstones. The metamorphosed pelite (03128 Table 1$)$ have positive (0.6) values of $\varepsilon \mathrm{Nd}(\mathrm{T})$ and provide relatively young two-stage $\mathrm{T}_{\mathrm{DM}}$ of $2.32 \mathrm{Ga}$.

The Baikal terrane basement complex is unconformably overlain by undeformed and unmetamorphosed post-collisional volcanic-sedimentary rocks of the Akitkan Formation. The age of the final eruption/igneous event for Akitkan Formation is 1.85 Ga (Larin et al., 2003). This age is considered reasonable for $\varepsilon \mathrm{Nd}(\mathrm{T})$ calculations for all of the Akitkan Formation volcanic rocks and co-magmaic them granitoids. The analysed basalts and andesite-basalts of lower part of the Formation demonstrate moderate LREE enrichment $\left({ }^{147} \mathrm{Sm} /{ }^{144} \mathrm{Nd}=0.1090-0.1188\right)$ and $\varepsilon \mathrm{Nd}(\mathrm{T})$ of -4.7 to -7.6 . The $\mathrm{Nd}$ model age of the samples from the lower part of the Akitkan Formation ranges between $2.65-2.93 \mathrm{Ga}$ (Table 1). The rhyolite and rhyolite-dacite from the middle part of Akitkan Formation (all close to A-type granite in their compositions) display stronger LREE enrichment $\left({ }^{147} \mathrm{Sm} /{ }^{144} \mathrm{Nd}\right.$ up to 0.066$)$ and more variable values of $\varepsilon \mathrm{Nd}(\mathrm{T})$ varying from -1.6 to -9.2 and $\mathrm{Nd}$ model ages from 2.38 up to $2.91 \mathrm{Ga}$. Neodymium model ages of rocks with the lowest $\varepsilon \mathrm{Nd}(\mathrm{T})$ values represent minimal mixing of young-juvenile and older crustal components; hence the basement of the Akitkan formation is likely to be at least of Mesoarchaean age (Fig. 2). The Nd isotope data of samples from the upper part of the Akitkan Formation $(\varepsilon N d(T)=-0.9$ to -4.8 and $\mathrm{Nd}$ model age range from 2.37 to $2.82 \mathrm{Ga}$ ) (Figs 2,3) confirm the significant involvement of the Mesoarchaean crustal material as a component in felsic and mafic volcanic sources.

Some A-type granites of the Baikal terrane are co-magmatic to Akitkan felsic volcanics and display clear similarities in $\mathrm{Nd}$ isotope characteristics (Table 1). The Palaeoproterozoic A-type granitoids are also enriched in LREE $\left({ }^{147} \mathrm{Sm} /{ }^{144} \mathrm{Nd}=0.1087\right.$ 0.1212 ), show wide variations of $\varepsilon \mathrm{Nd}(\mathrm{T})$ values (-1.4 to -8.0) and $\mathrm{Nd}$ model ages from 2.40 up to $2.81 \mathrm{Ga}$ (Figs 2, 3). Such variation could be explained by mixing the Palaeoproterozoic juvenile material and older crustal component of the Baikal terrane basement.

Juvenile-type relicts, described in the Chuya Unit (Fig. 1b) (Neymark et al., 1998) are represented by $2.02 \mathrm{Ga}$ arc-related Chuya granites (Table 1) with $\varepsilon \mathrm{Nd}(\mathrm{T})$ values ranging from +1.3 to +1.8 and $\mathrm{Nd}$ model ages between $2.29-2.33 \mathrm{Ga}$.

Small massifs of A-type granite occur in the Chuya Unit have $\varepsilon N d(T)$ values from 0.1 to -1.3 and $\mathrm{Nd}$ model ages range from 2.29 to $2.40 \mathrm{Ga}$. However, in contrast to A-type granitoids which are co-magmatic to Akitkan felsic volcanics, the source of the Chuya unit A-type granites (Abchada complex) appears to be Palaeoproterozoic juvenile crust (Fig. 2) (Neymark et al., 1998).

Three different groups of dolerite dykes intruding the Baikal terrane were investigated for Sm-Nd systematic (Table 1). The oldest dykes are thought to be synchronous with felsic volcanic rocks of the Akikan Formation $(\sim 1.85 \mathrm{Ga}$, our U-Pb zircon SHRIMP data unpublished). The dolerites show a narrow range of $\varepsilon \mathrm{Nd}(\mathrm{T})$ values (from -5.6 to -8.8 ) and $\mathrm{Nd}$ model ages between 2.74 to $3.33 \mathrm{Ga}$ (Table 1, Fig. 3). Nd isotope data for 1.67 Ga dolerite shows $\varepsilon N d(T)=-3.8$ and $\mathrm{Nd}$ model age 2.57. The $\varepsilon N d(T)$ estimated for 
Neoproterozoic (Gladkochub et al., 2006) dolerites range between -19.2 to -20.9 and demonstrate significant contamination of basaltic magma by very older crustal material. $\mathrm{Nd}$ model ages obtained for these dolerites are $3.40-3.46 \mathrm{Ga}$ and indicate the likely presence of older crust deep in the Baikal terrane. Such a result is consistent with geochemical characteristics reported by Gladkochub et al. (2007).

\section{Discussion}

Increasing evidence, particularly from recent studies on $\mathrm{Nd}$ model ages supports the recycling of Palaeo- and Eoarchaean crust during Palaeoproterozoic granite intrusion in the southern Siberian craton. In the Sharizhalgai terrane the period 3.4-3.6 Ga represents early crust formation as determined from $\mathrm{Nd}$ isotope composition of basement granulite and TTGorthogneisses. The mafic xenoliths from these basement rocks provide evidence of the existence of juvenile crust in the area perhaps as old as $3.9 \mathrm{Ga}$ (Table 1). Nd isotopic data indicate that the Birusa and Goloustnaya terranes separated by Sharizhalgai and Urik-Iya terranes are underlain by younger crust (2.8 and 2.6 Ga respectively). Further of the Goloustnaya terrane, early crust is locally present in the Baikal terrane as indicated by $\mathrm{Nd}$ ages of 3.0 - 3.2 Ga. Much older Nd model ages of 3.4-3.5 Ga from the dolerite dykes indicate that older crust has been also involved in the generation of mafic magma.

The distribution of different $\mathrm{Nd}$ model ages throughout the southern Siberian craton indicates a significant heterogeneity of the crustal protoliths (Fig. 3).

The Urik-Iya and Chuya units are relicts of Palaeoproterozoic $(\sim 2.0-2.3 \mathrm{Ga})$ juvenile crust within the studied segment of the Siberian craston margin. The Chuya unit is interpreted as a Palaeoproterozoic island-arc reworked during major 1.9-2.0 Ga orogenesis. The juvenile nature of the Urik-Iya Palaeoproterozoic crust suggests that at $2.0 \mathrm{Ga}$ the Birusa terrane was not in direct contact with the older Sharizhalgai terrane. Moreover, the $\mathrm{Nd}$ isotopic characteristics of Archaean rocks from the Sharizhalgai terrane contrast with those of the Birusa terrane, confirming that, although their Proterozoic evolution has been parallel, the two terranes did not share a common Archaean history. High-grade (up to eclogite facies) metamorphosed mafic-ultramafic relicts in the eastern side of the Urik-Iya terrane mark the boundary of these two terranes whose assembly probably occurred around 1.9 Ga during a Palaeoproterozoic accretion-collision event.

The Nd isotope data of Neoarchaean collisional type granites and numerous Palaeoproterozoic post-collisional granite plutons (excluding the Abchada granite of the Chuya Unit) indicates that all of these intrusions inherited their $\mathrm{Nd}$ isotope composition from the Palaeo- to Neoarchaean basement from which they were derived and through which they passed. Moreover the Palaeo- and Neoproterozoic mafic dykes in the studied terranes also show a contamination by older basement in their $\mathrm{Nd}$ isotope record. 
This synthesis of new $\mathrm{Nd}$ isotope highlights the significance of $\mathrm{Nd}$ isotope data for constraining the crustal growth processes responsible for the evolution of the Siberian craton. The data provides evidence that the southern part of the Siberian craton preserves a long history of crustal development extending from the Neoproterozoic as far back as Eoarchaean. The complicated and heterogenous structure of the southern Siberian craton indicates that the craton formed from a series of distinct Archaean crustal fragments with different histories (Fig. 3) that were amalgamated by Palaeoproterozoic accretion between 2.0-1.9 Ga. Following amalgamation, voluminous granites were intruded at $\sim 1.85$ Ga into the Archaean crustal units and the suture zones separating them. These granites mark the final stage of the stabilization of the southern Siberian craton. The assemblage of Siberia broadly coincides with important orogenic events on nearly every Precambrian continent (Windley, 1998; Zhao et al 2002), suggesting that the evolution of the southern part of the Siberian craton reflects its involvement in the amalgamation of a Palaeoproterozoic supercontinent (Condie, 2002; Zhao et al , 2002).

\section{Acknowledgements}

Authors are grateful to V.P. Kovach (IPGG RAS), Yu. A. Paholchenko (IGC SB RAS) and A.M. Agashev (IGM SB RAS) for help in sample preparation and analysis. This research was supported in part by grants of Russian Ministry of Education (MD 242.2007.5, NSH 3082.2008.5), Russian Foundation for Basic Research (08-05-00245, 08-05-98070) and Research-Education Centre "Baikal” of Irkutsk State University (RNP 2.2.1.1.7334). 


\section{References}

Aftalion, M., Bibikova, E.V., Bowes, D.R., Hopwood, A.M. \& Perchuk, L.L. 1991 Timing of Early Proterozoic collisional and extensional events in the granulite-gneisscharnokite-granite complex, lake Baikal, USSR: A U-Pb, Rb-Sr and Sm-Nd isotopic study. The Journal of Geology, 99, 851-861

Arndt, N.T. \& Goldstein, S.I. 1987. Use and abuse of crustal formation ages. Geology, 15, 893-895.

Barovich, K. M. \& Patchett, P.J. 1992. Behaviour of isotopic systematics during deformation and metamorphism: a $\mathrm{Hf}, \mathrm{Nd}$ and $\mathrm{Sr}$ isotope study of milonitized granite. Contribution to Mineralogy and Petrology, 109, 386-393.

Bayanova, T.B. 2004. The age of the key geological complex of the Kola region and duration of the magmatic processes. Nauka, Saint-Petersburg, 174 p. (in Russian).

Bibikova, E.V., Korikovsky, S.P., Kirnozova, T.I., Sumin, L.V., Arakelyants, M.M., Fedorovsky, V.S. \& Petrova, Z.I. 1987. Age determinations of the rocks of the Baikal-Vitim greenstone belt by isotopic geochronological methods. In: Shulyukov, Yu.A. (ed), Isotopic dating of the metamorphic and metasomatic processes. Nauka, Moscow, 154-164 (in Russian).

Bibikova, E. V., Turkina, O.M., Kirnozova, T.I., Fugzan M.M. 2006. Ancient Plagiogneisses of the Onot Block of the Sharyzhalgai Metamorphic Massif: Isotopic Geochronology. Geochemistry International, 44 (3), 310-322.

Bock, B., McLennan \& Hanson, G.N. 1994. Rare earth element redistribution and its effects on the $\mathrm{Nd}$ isotope system in the Austin Glen Member of the Normanskill Formation. New York, USA. Geochimica et Cosmochimica Acta, 58, 5245-5253.

Bros, R., Stille, P., Gauthier-Lafaye, F., Weber, F. \& Clauer, N. 1992. Sm-Nd isotope dating of Proterozoic clay mineral: an example from the Francevillian sedimentary series, Gabon. Earth Planetary Science Letters, 113, 207-218.

Chappell, B.W. \& White A.J.R. 1974. Two contrasting granite types. Pacific Geology, 8, 173-174.

Condie, K. C. \& Rosen, O. M. 1994. Laurentia-Siberia connection revisited. Geology, 22, 168-170.

Condie, K.C. 2002. Breakup of a Paleoproterozoic supercontinent. Gondwana Research, 5, 41-43.

Cullers, R.L., Bock, B. \& Guidotti, C. 1997. Elemental distributions and Nd isotopic compositions of Silurian metasediments, western Maine, USA: redistribution of rare earth elements, Geochimica et Cosmochimica Acta, 61, 1847-1861. 
DePaolo, D.J. \& Wasserburg, G.J. 1976. Nd isotopic variations and petrogenetic models. Geophysics Research Letters, 3, 249-252.

Dickin, A.P. 2005. Radiogenic isotope geology ( $\left.2^{\text {nd }} e d.\right)$. Cambridge University press, Cambridge.

Donskaya, T.V., Sklyarov, E.V., Gladkochub, D.P., Mazukabzov, A.M., Salnikova, E.B., Kovach, V.P., Yakovleva, S.Z. \& Berezhnaya, N.G. 2000. The Baikal collisional metamorphic belt. Doklady Earth Sciences, 374, 1075-1079.

Donskaya, T. V., Sal'nikova, E. B., Sklyarov, E. V., Gladkochub, D. P., Mazukabzov, A. M., Kovach, V. P., Yakovleva, S. Z., Berezhnaya, N. G., 2002. Early Proterozoic Postcollision Magmatism at the Southern Flank of the Siberian Craton: New Geochronological Data and Geodynamic Implications. Doklady Earth Sciences, 383, 125 128.

Donskaya, T.V., Bibikova, E.V., Mazukabzov, A.M., Kozakov, I.K., Gladkochub, D.P., Kirnozova, T.I., Plotkina, Yu.V., Reznitsky, L.Z. 2003. The Primorsky granitoid complex of western Cisbaikalia: geochronology and geodynamic typification. Russian Geology and Geophysics, 44, 968-979.

Donskaya, T.V., Gladkochub, D.P., Mazukabzov, A.M., Poller, U., Todt, W. 2005a. Archean of Cisbaikalia: new geochronological, geochemical and isotopic data. In: Glebovitsky, V.A. (Ed.), Archean Geology and geodynamic, abstract volume. CIC, SanktPeterburg, 108-113 (in Russian).

Donskaya, T. V., Gladkochub, D. P., Kovach, V. P., Mazukabzov, A. M., 2005 b. Petrogenesis of Early Proterozoic Postcollisional Granitoids in the Southern Siberian Craton. Petrology, 13, 229-252.

Donskaya, T.V., Gladkochub, D.P. \& Mazukabzov, A.M. 2005c. Petrogenesis of Early Proterozoic two-mica granite of the Birusa terrane. In. Mitrofanov F.P. (ed.) The origin of igneous rocks, abstract volume. KSC RAN, Apatite, 73-74 (in Russian).

Donskaya, T.V., Mazukabzov, A.M., Bibikova, E.V., Gladkochub, D.P., Didenko, A.N., Kirnozova, T.I., Vodovozov, V.Yu. \& Stanevich, A.M. 2007. Stratotype of the Chaya Formation of the Akitkan Group in the North Baikal volcanoplutonic belt: age and time of sedimentation. Russian Geology and Geophysics, 48, 707-710.

Gladkochub, D. P., Donskaya, T. V., Mazukabzov, A. M., Sklyarov, E. V., Ponomarchuk, V. A. \& Stanevich, A. M., 2002. The Urik-Iya Graben of the Sayan Inlier of the Siberian Craton: New Geochronological Data and Geodynamic Implications. Doklady Earth Sciences, 386, 74-78.

Gladkochub, D.P., Sklyarov, E.V., Men'shagin, Yu.V. \& Mazukabzov, A.M., 2001 a. Geochemistry of Ancient Ophiolites of the Sharyzhalgai Uplift. Geochemical International, 39(10), 947-959.

Gladkochub, D.P, Sklyarov, E.V, Donskaya, T.V, Mazukabzov, A.M, Menshagin, Yu.V. \& Panteeva, S.V. 2001b. Petrology of gabbro-dolerites from Neoproterozoic dike 
swarms in the Sharyzhalgai Block with reference to the problem of breakup of the Rodinia supercontinent. Petrology, 9(6), 560-577

Gladkochub, D.P., Donskaya, T.V., Mazukabzov, A.M., Salnikova, E.B., Sklyarov, E.V.\& Yakovleva, S.Z. 2005. Kitoy granite complex (southern part of the Siberian Craton): composition, age,geodynamic setting. Russian Geology and Geophysics, 46(11), 1121-1133.

Gladkochub, D., Pisarevsky, S., Donskaya, T., Natapov, L.M., Mazukabzov, A., Stanevich, A.M. \& Slkyarov, E. 2006a. Siberian Craton and its evolution in terms of Rodinia hypothesis. Episodes, 29(3), 169-174.

Gladkochub, D.P., Wingate, M.T.D., Pisarevsky, S.A., Donskaya, T.V., Mazukabzov, A.M., Ponomarchuk, V.A. \& Stanevich, A.M. 2006b. Mafic intrusions in southwestern Siberia and implications for a Neoproterozoic connection with Laurentia. Precambrian Research, 147, 260-278.

Gladkochub, D.P., Donskaya, T.V., Mazukabzov, A.M., Stanevich, A.M., Sklyarov, E.V. \& Ponomarchuk, V.A. 2007. Signature of Precambrian extension events in the southern Siberian craton. Russian Geology and Geophysics, 48(1), 17-41

Gladkochub, D.P., Donskaya, T.V., Wingate, M. T. D., Poller, U., Kröner, A., Fedorovsky, V.S., Mazukabzov, A.M., Todt, W. \& Pisarevsky S.A. 2008. Petrology, geochronology, and tectonic implications of c. 500 Ma metamorphic and igneous rocks along the northern margin of the Central-Asian Orogen (Olkhon terrane, Lake Baikal, Siberia). Journal of the Geological Society, London, 165(1), 235-246.

Goldstein, S.J. \& Jacobsen, S.B. 1988. Nd and Sr isotopic systematics of rivers water suspended material: implications for crustal evolution. Earth and Planetary Science Letter, 87, 249-265.

Jacobsen, S.B. \& Wasserburg, G.J. 1984. Sm-Nd evolution of chondrites and a chondrites, II. Earth and Planetary Science Letters, 67, 137-150.

Jahn, B.M. \& Condie, K.C. 1995. Evolution of the Kaapvaal craton as viewed from geochemical and Sm-Nd isotopic analyses of intracratonic pelites. Geochimica et Cosmochimica Acta, 59, 2239-2258.

Keto, L.S. \& Jacobsen, S.B. 1987. Nd and Sr isotope variations of Early Paleozoic oceans. Earth and Planetary Science Letter, 84, 27-41.

Larin, A.M., Sal'nikova, E.B., Kotov, A.B., Kovalenko, V.I., Rytsk, E.Yu., Yakovleva, S.Z., Berezhnaya, N.G., Kovach, V.P., Buldygerov, V.V. \& Sryvtsev, N.A. 2003. The North Baikal Volcanoplutonic Belt: Age, Formation Duration, and Tectonic Setting. Doklady Earth Sciences, 392, 963-967.

Larin, A.M., Sal'nikova, E.B., Kotov, A.B., Makar'ev, L.B., Yakovleva, S.Z. \& Kovach, V.P. 2006. Early Proterozoic syn- and postcollision granites in the northern part of the Baikal Fold Area. Stratigraphy and Geological Correlation, 14(5), 463-474. 
Levitskii, V.I., Mel'nikov, A.I., Reznitskii, L.Z., Bibikova, E.V., Kirnozova, T.I., Kozakov, I.K., Makarov, V.A. \& Plotkina, Yu.V. 2002. Early Proterozoic postcollisional granitoids in southwestern Siberian craton. Russian Geology and Geophysics, 43, 679-692.

Liew, T.C., Finger, F. \& Höck, V. 1989. The Moldanubian granitoid plutons of Austria: Chemical and isotopic studies bearing on their environmental setting. Chemical Geology, 76, 41-55.

Makrigina, V.A., Petrova, Z.I., Sandimirova, G.P. \& Pakholchenko, Yu.A., 2005. New data on the age of the strata framing the Chuya and Cisbaikalian uplifts (northern and western Baikal areas). Russian Geology and Geophysics, 46 (7), 714-722.

McCullogh, M.T. 1987. Sm-Nd isotopic constraints on the evolution of Precambrian crust in the Australian continent. In: Kroner, A. (ed.) Proterozoic Lithospheric Evolution. Geodynamic Series, 17. American Geophysical Union, Washington, DC, 115-130.

Neymark, L.A., Ritsk, E.Yu., Levchenkov, O.A., Komarov, A.N., Yakovleva, S.Z., Nemchin, A.A., Schuleschko, I.K., Korikovskii, S.P., 1990. About Early Proterozoic Upper Riphean ages of rocks of the Olokit complex (Northern Cis-Baikalia) on based zircon geochronological data. In: Schemyakin, V.M. (Ed.), Precambrian geology and geochronology of the Siberian platform and its surround. Nauka, Leningrad, 206-222 (in Russian).

Neymark, L.A., Kovach, V.P \& Nemchin A.A. 1993. Late Archean intrusive complexes in the Olekma granite-greenstone terrane (Eastern Siberia): geochemical and isotopic study. Precambrian Research, 62(4), 453-472.

Neymark, L. A., Larin, A. M., Yakovleva, S. Z., Sryvtsev, N.A. \& Buldygerov, V.V. 1991. New Data on the Age of the Akitkan Group, Baikal-Patom Foldbelt: Constraints from U-Pb Dating of Zircons. Dokladi Akademii Nauk SSSR, 320, 182-186 (in Russian).

Neymark, L. A., Larin, A. M., Nemchin, A.A., Ovchinnikova, G.V. \& Rytsk, E.Yu. 1998. Anorogenic nature of magmatism in the Northern Baikal volcanic belt: evidence from geochemical, geochronological (U-Pb), and isotopic ( $\mathrm{Pb}, \mathrm{Nd})$ data. Petrology, 6, 124-148.

Nutman, A.P., Chernyshev, I.V., Baadsgaard, H. \& Smelov, A.P. 1992, The Aldan shield of Siberia, USSR: the age of its Archaean components and evidence for widespread reworking in the Mid-Proterozoic. Precambrian Research, 54, 195-210.

Parfenov, L. M. \& Kuzmin, M.I. 2001, Tectonics, Geodynamics, and Metallogeny of the Sakha Republic (Yakutia). MAIK Nauka, Interperiodica, Moscow (in Russian).

Poller, U., Gladkochub, D. P., Donskaya, T. V., Mazukabzov, A. M., Sklyarov, E. V. \& Todt, W. 2004, Early Proterozoic collisional magmatism along the Southern Siberian craton - constrains from $\mathrm{U}-\mathrm{Pb}$ single zircon data. Transactions of the Royal Society Edinburgh, 152, 1116-1127.

Poller, U., Gladkochub, D., Donskaya, T., Mazukabzov, A., Sklyarov, E. \& Todt W. 2005. Multistage magmatic and metamorphic evolution in the Southern Siberian Craton: 
Archean and Paleoproterozoic zircon ages revealed by SHRIMP and TIMS. Precambrian Research, 136, 353-368.

Poller, U., Kohut, M., Todt, W. \& Janak, M. 2001. Nd, Sr, Pb isotope study of the Western Carpathians: implications for Paleozoic evolution. Schweizerische MineralogischPetrographische Mitteilungen, 81, 159-174.

Rosen, O.M., Condie, K.C, Natapov, L.M. \& Nozhkin, A.D. 1994. Archean and Early Proterozoic evolution of the Siberian craton: a preliminary assessment. In: Condie, K.C.(ed.), Archean Crustal Evolution. Elsevier, Amsterdam, 411-459.

Rosen, O.M., Manakov, A.V.\& Serenko, V.P. 2005. Paleoproterozoic collisional system and diamondiferous lithospheric keel of the Yakutian kimberlite province. Russian Geology and Geophysics, 46, 1259-1272.

Sal'nikova, E.B., Kotov, A.B., Levitskii, V.I., Reznitskii, L.Z., Mel'nikov, A.I., Kozakov, I.K., Kovach, V.P., Barash, I.G. \& Yakovleva S.Z. 2007. Age Constraints of High-Temperature Metamorphic Events in Crystalline Complexes of the Irkut Block, the Sharyzhalgai Ledge of the Siberian Platform Basement: Results of the U-Pb Single Zircon Dating. Stratigraphy and Geological Correlation, 15, 343-358.

Sklyarov, E.V., Gladkochub, D.P., Mazukabzov, A.M. \& Menshagin, Yu.V. 1998. Metamorphism of the Ancient Ophiolites of the Sharyzhalgai. Russian Geology and Geophysics, 39(12), 1722-1739.

Sklyarov, E.V., Gladkochub, D.P., Mazukabzov, A.M., Menshagin, Y.V., Watanabe, T. \& Pisarevsky, S.A. 2003. Neoproterozoic mafic dike swarms of the Sharyzhalgai metamorphic massif (southern Siberian craton). Precambrian Research, 122, 359-376.

Stille, P. \& Clauer, N. 1986. Sm-Ns isochron-age and provenance of the argillites of the Gunflint Iron Formation in Ontario, Canada. Geochimica et Cosmochimica Acta, 50, 1141-1146.

Taylor, S.R. \& McLennan, S.M. 1985. The continental crust: its composition and evolution. Blackwell, Oxford Press.

Turkina, O.M. 2004. The amphibolite plagiogneiss complex of the Onot Block, Sharyzhalgai Uplift: isotopic geochemical evidence for the Early Archean evolution of the continental crust. Doklady Earth Sciences, 399, 1296-1300.

Turkina, O. M. 2005. Proterozoic Tonalites and Trondhjemites of the Southwestern Margin of the Siberian Craton: Isotope Geochemical Evidence for the Lower Crustal Sources and Conditions of Melt Formation in Collisional Settings. Petrology, 13, 35-48

Turkina, O. M., Bibikova, E. V. \& Nozhkin, A. D. 2003. Stages and Geodynamic Settings of Early Proterozoic Granite Formation on the Southwestern Margin of the Siberian Craton. Doklady Earth Sciences, 388, 159-163.

Turkina, O. M., Nozhkin, A. D. \& Bayanova, T. B. 2006. Sources and Formation Conditions of Early Proterozoic Granitoids from the Southwestern Margin of the Siberian Craton. Petrology, 14, 262-283. 
Turkina, O.M., Nozhkin, A.D., Bayanova, T.B. \& Dmitrieva N.V. 2007. Isotopic Provinces and Evolution Stages of the Precambrian Crust at the Southwestern Margin of the Siberian Craton and Its Folded Framing, Doklady Earth Sciences, 413, 481-486.

Whalen, J.B., Currie, K.L. \& Chappell, B.W. 1987. A-type granites: geochemical characteristics, discrimination and petrogenesis. Contribution to Mineralogy and Petrology, 95, 407-419.

White, W. M. \& Patchett, J. 1984. Hf-Nd-Sr isotopes and incompatible element abundances in island arcs: implications for magma origins and crust-mantle evolution. Earth and Planetary Science Letter, 67, 167-185.

Whitehouse, M.J. 1988. Granulite facies Nd-isotopic homogenisation in the Lewisian complex of northwest Scotland. Nature, 331, 705-707.

Windley, B.F. 1998. The Evolving Continents. N.Y.: Wiley and Sons.

Zhao, G., Cawood, P.A., Wilde, S.A., Sun, M. 2002. Review of global 2.1-1.8 Ga orogens: implications for a pre-Rodinia supercontinent. Earth Science Reviews, 59, 125-162.

\section{Figure captions}

Fig. 1. The tectonic scheme of the Siberian craton after Rosen et al. (2005) (a) and Scheme The distribution of the major tectonic units of the Siberian craton (a) with detail of these tectonic units shown in (b).

Fig. 2. $\varepsilon N d(T)$ vs primary age diagram for rocks of major terranes \& units of the southern Siberian craton. Shaded areas correspond to $\mathrm{Nd}$ isotope evolution fields.

Fig.3. A compilation of Nd-model ages of major terranes \& domains within the southern Siberian craton. 


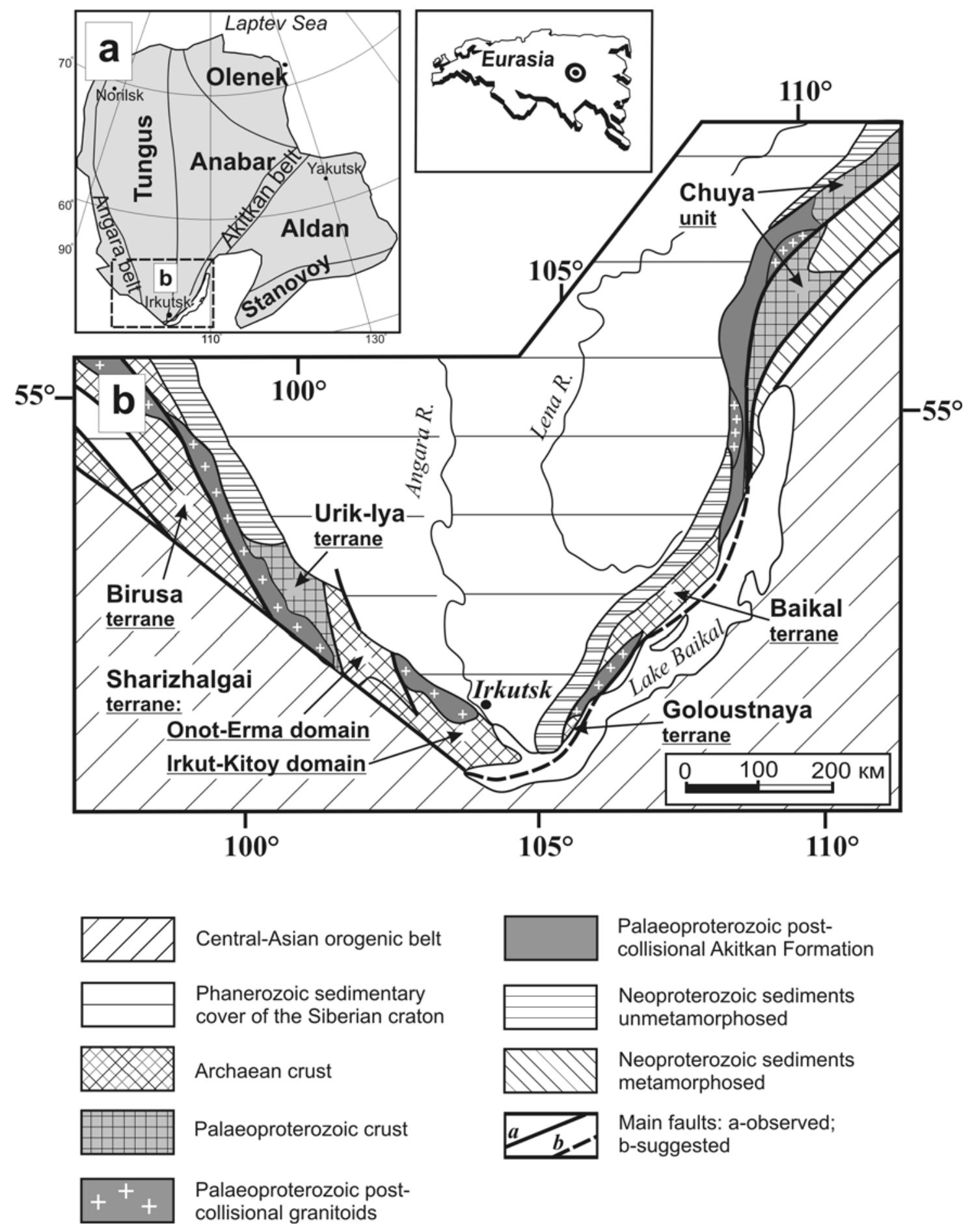


Birusa terrane

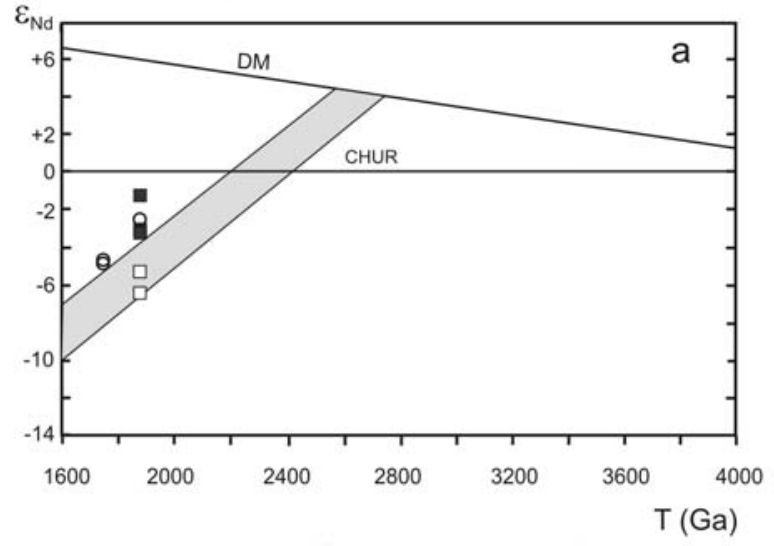

Irkut-Kitoy domain (Sharizhalgai terrane)

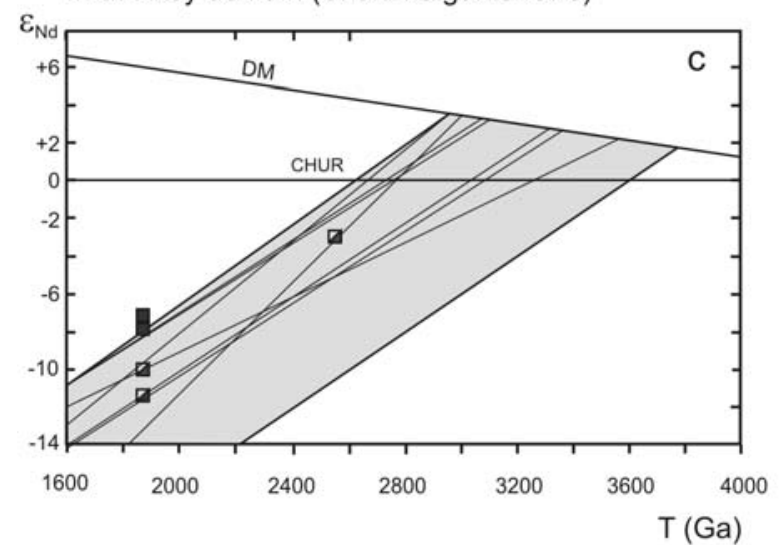

Onot-Erma domain (Sharizhalgai terrane)

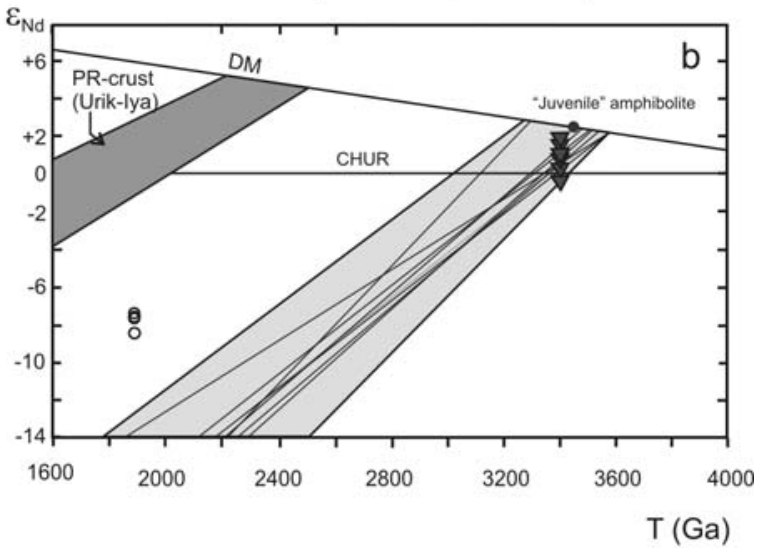

Baikal terrane

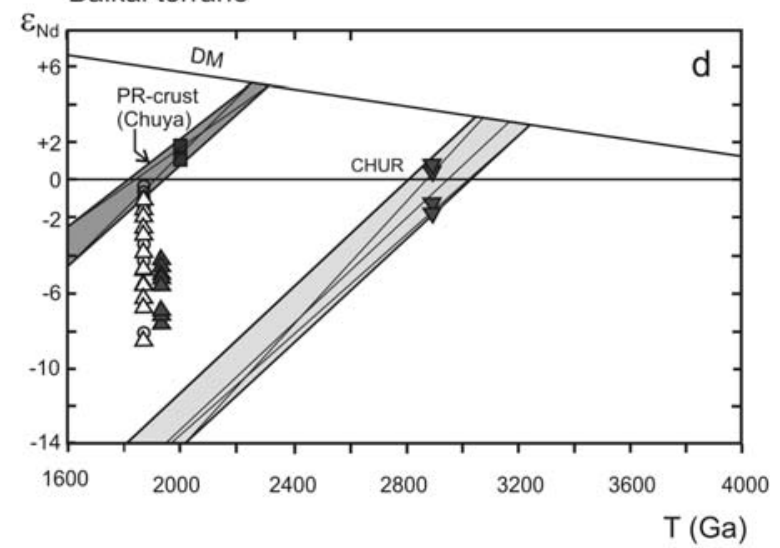

$\nabla$ TTG-series

- I-type granite

$\square$ S-type granite

a I-S-type granite

O A-type granite

A Akitkan Formation mafic volcanics $\triangle$ Akitkan Formation felsic volcanics $\square$ Archaean crust $\square$ Palaeoproterozoic crust

Note: The symbols are given for samples provided by U-Pb zircon emplacement age 


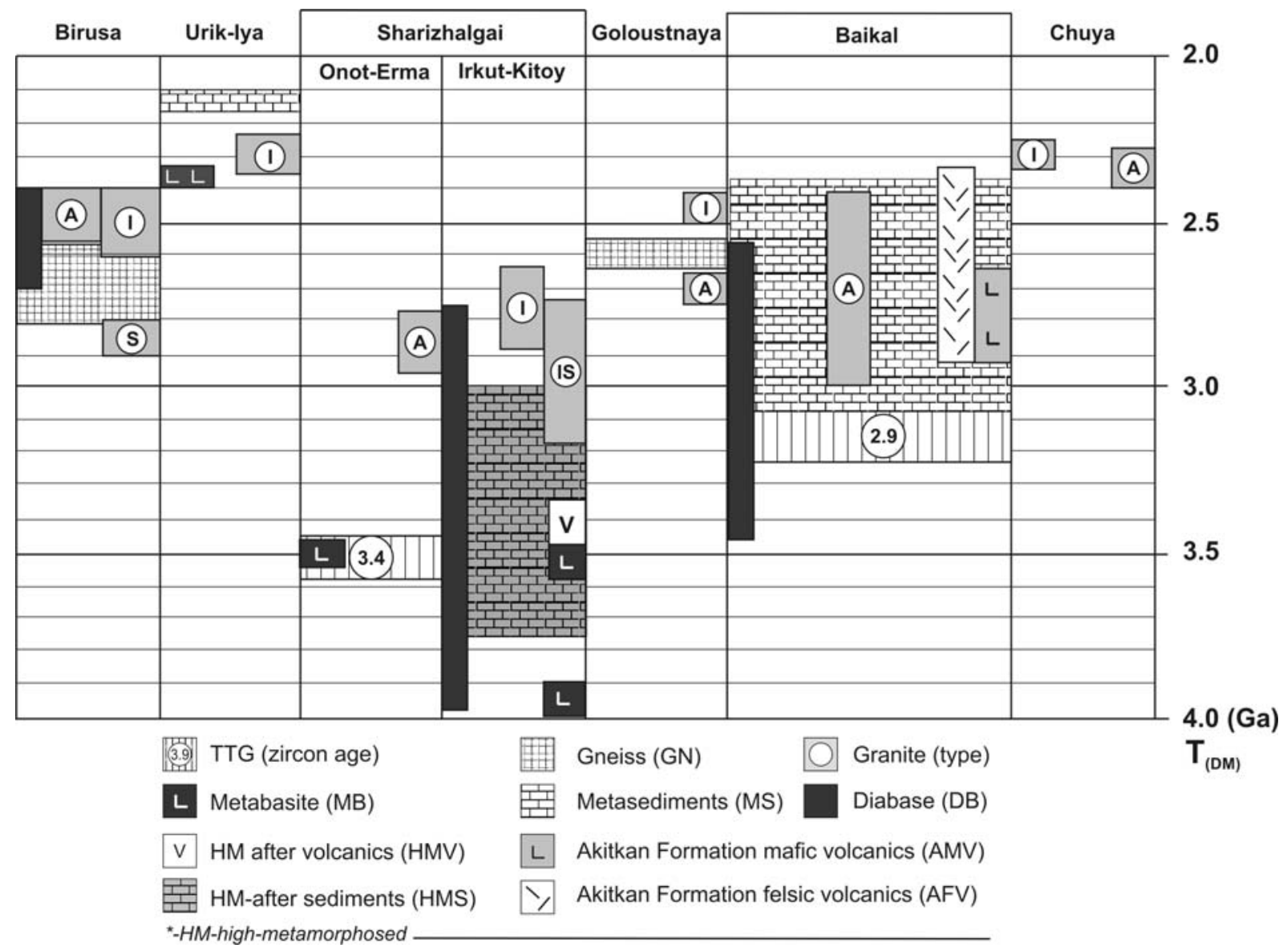

